\title{
Jacques Derrida’s Literary View of “Différance” Speech Acts
}

\author{
Cunjiu Kuang ${ }^{1, \text { a }}$ \\ ${ }^{1}$ College of Humanities, Sichuan Agricultural University, Ya’an, Sichuan Province, 625104, China \\ a Email: 476033678@qq.com
}

Keywords: Derrida; différance; speech act

\begin{abstract}
Deeply influenced by Austin's and Searle’s speech act theory, Jacques Derrida puts forward a series of deconstructive views, such as literature being a différance act and as a social institution of speech acts, and deconstructs the binary opposition between literary discourse and everyday discourse, meaning certainty, and rules, etc., which have directly or indirectly affected the research line and direction of deconstructive literary theory.
\end{abstract}

\section{Controversy: Derrida's Appropriation of Speech Act Theory}

Jacques Derrida (1930-2004) is the originator of the contemporary influential thoughts of deconstruction, and he was profoundly influenced by Austin's and Searle's speech act theory, with his discussions on the speech act theory pervasive throughout his life of philosophy. He himself even puts it, "... to be in many respects quite close to Austin"; "both interested in and indebted to his problematic". He explores many deconstruction thoughts in the speech act theory, and extensively applies the concepts of speech act and its thoughts, which is used as a deconstruction strategy, including the binary opposition between literary discourse and everyday course, context determination and uncertainty of meaning, and repetition and différance of rules. Despite traces of alteration and appropriation, his deconstruction thoughts have exerted a significant impact on people such as Fish, Deman, Keller, Miller, Butler, and he proposes a series of literary views of speech acts, directly or indirectly affecting the research line and trend of deconstructionist literary theory. It is even believed in The Cambridge History of Literary Criticism that, the speech act theory is remembered mostly due to Jacques Derrida's deconstruction theory, which fully demonstrates the profound impact of the speech act theory on Derrida and also the active role of Derrida's deconstruction thoughts in disseminating the speech act theory.

Nonetheless, the relationship between the speech act theory and the deconstruction thoughts are not always smooth. The 1970s saw a decade-long debate between Derrida and Searle, which is conventionally understood as the first direct confrontation between the European deconstruction thoughts and the Anglo-American analytic philosophy, and also as the origin of the research line of deconstructive speech acts. In 1977, targeting at the critique of Austin's speech act theory in "Signature Event Context" published by Derrida in 1971, John Searle published an article "Reiterating the Differences: A Reply to Derrida" on Glyph in 1977, arguing for Austin's speech act theory. In the same year, Glyph published Derrida's article "Limited Inc abc ..." (1977), and purposefully misspelled Searle's name as “Sarl”, making a playful reply. In 1994, Searle made replies in his "Literary Theory and Its Discontents" to Derrida's concepts such as "uncertainty" of text meaning. This round of debate between Derrida and Searle revolved around Austin's speech act theory, in which the two figures explicitly expressed their respective standpoints and viewpoints, criticized and counter-criticized thoughts based on different traditional backgrounds. Although there were numerous "misreadings", misunderstandings, and even "theoretical violence", they could be regarded as a critical innovation of the speech act theory by Derrida, which, to a great extent, attracted European scholar's attention to the speech act theory. 


\section{Deconstruction: Iterability, Meaning Uncertainty and Addition of Speech Acts}

Jacques Derrida reconstructed Searle's speech act view from the perspective of deconstruction. For him, apart from literary discourses, “'good' literary criticism, the only worthwhile kind, implies an act, a literary signature or counter-signature, an inventive experience of language, in language, an inscription of the act of reading in the field of the text that is read. This text never lets itself be completely 'objectified'”. For Searle, speech acts act by rules, so Searle especially values the interpretation of conventions and rules of everyday speech acts. For him, the smooth performance of everyday speech acts depends on some potential rules or the satisfaction of conditions. Repeated citations of rules do not necessarily mean the lost of "original meaning" in the discourse itself. Correspondingly, Derrida also thinks highly of the use of language rules, and he holds that one can not speak without mastering certain language rules Nonetheless, from continuous use of these rules and conditions, Derrida further extracts "iterability" and "infinitive différance", etc. He takes the act of "signature" as an example. In his view, each signature act, just like each speech act in the real world, is an original act, continuous iteration of conventions, and also the contradictory and intertwined result of iteration and originality. The iteration is not a simple copy or citation, as each iteration of speech will "add" something new and produce new meanings. So is the literary text. For him, it is, as a speech act, "both a doing and an imitation of doing, both a performance and a record, both an event and a law". Under double restraints of context and conventions, literary speech acts are innovated through repeated iterations and form new literary discourses. It is the dual attributes of convention and innovation that create endless power in language or writing and provide some legality for the occurrence of single events or speech acts; sometimes, they become a "model" and thus theoretical rules with universality. Searle claims that speech acts are the tool for language communication, and the dominant role in speech acts is the intention of the speaker or author. For Derrida, however, language is the home of existence, and the dominant role in speech acts is not the subjective consciousness, but the structure, rules or codes of language.

Derrida deconstructed the concept of contextual "determination" of meaning in Searle's speech act theory. Austin and Searle hold that the generation of meaning may depend on the context: "for some years we have been realizing more and more clearly that the occasion of an utterance matters seriously, and that the words used are to some extent to be 'explained' by the 'context' in which they are designed to be or have actually been spoken in a linguistic interchange". Searle also holds that, once with the background ability or intentional network, the speaker and the listener master the common linguistic tool, and then the meaning and the communication can be completely determined. That is to say, if a certain discourse is put under a specific context, its meaning can be fully accurately determined. From his perspective of deconstruction, Derrida was devoted to subvert the concept that the text language has determined meanings. For him, although meaning is context-bound, context is elusive and boundless; thus, it remains difficult to determine the meaning. "This is my starting point. No meaning can be determined out of context, but no context permits saturation. What I am referring to here is not richness of substance, semantic fertility, but rather structure, the structure of the remnant or of iteration.” That is to say, the context structure is open, and unconscious desire is also a factor that needs to be considered in context; many times, the context becomes unpredictable. Further, context coding limits or fixes a certain context, but creates a new context that escapes coding. This also causes a "différance" or permanent gap between the signifier and the signified in the language, so that people can never accurately grasp the exact linguistic meaning. According to the idea of force proposed by Searle, there is deep force in addition to the literal meaning, and the view of "meaning beyond words" is affirmed. By contract, Derrida attracted attention, to some extent, to situations such as "utterances do not express the intention" and "utterances differ from the intention", so that phenomena such as "misreading" and "misunderstanding” occur. In a certain sense, the two are not completely opposite, and there are some similarities.

Based on the concept of deconstruction, Derrida criticizes and deconstructs the binary opposition between literary discourses and everyday discourses. In Searle's opinion, although Austin has put forward the concept of "everyday discourse", the concept itself is aimed at "scientific discourse" 
rather than "literary discourse", and it does not involve the binary opposition between everyday discourses and literary discourses. According to Searle, Austin mainly emphasizes a relationship of logical dependence, as fictional discourse is an imitation of everyday discourse. If there was no serious discourse, then there would be no fictional discourse category. Similarly, "how can the serious be defined or postulated without reference to the nonserious". Therefore, Searle believes that Austin is concerned with the samples of normative language expressions, focusing on eliminating all complex, derivative, parasitic and abnormal expressions, which is more conducive to research. Derrida, however, does not approve of this "logical priority" of everyday discourse proposed by Searle. In his view, although Austin used "performative utterance" instead of "constative utterance" and replaced "truth value" with "power”, which quite resembles Friedrich Nietzsche’s style, Austin unconsciously, in his process of pulling performative utterances from the edge back to the center, pushed the "literary discourse" into another set of binary oppositional frameworks and marginalized it, still unable to get rid of the shackles of "metaphysics of presence”. Austin and Searle regard literature as a parasitic discourse. For him, literary discourse is "parasitic upon its normal use", "which fall under the doctrine of the etiolations of language". And Derrida's goal of interpretation is mainly to deconstruct the "logocentrism" and "metaphysics of presence" that appear in traditional Western philosophy, such as deconstructing those things that are considered to be centers, keys, cores, focuses, emphasis, etc., so as to restore the status of those once considered to be marginal, parasitic, secondary, and irregular. Therefore, Derrida's deconstructivist strategy is not only to blur the boundaries between everyday discourse and literary discourse, but also to find and break the hierarchical order in the binary opposition model in the real world, and then to disintegrate this traditional logical thinking mode. It is a more magnificent deconstruction goal. Derrida carried out a series of deconstructive criticisms of speech act theory, including the critical deconstruction of a series of distinctions between "serious discourse/fictional discourse, literal/metaphorical, everyday discourse/parasitic discourse, normative/non-derived”. Derrida criticized Searle's concepts of "logical dependence" and "logical priority". For him, "What logician, what theoretician in general, would have dared to say: B depends logically on A, therefore B is parasitic, nonserious, abnormal, etc.?”. In his view, Austin's and Searle’s binary distinctions lack some obvious evidence. According to him, these binary distinctions obviously imply a kind of derogatory value judgment, so they are not just simple logical derivative relations. Derrida's deconstruction of the relationship between literary discourse and everyday discourse ultimately believes that the two are in a mutually complementary, parallel relationship, not a relationship of opposites, the center and the edge, or the subject and the parasite, and literature is not that kind of dispensable, "hollow, void", or "pretended, fictional" things. There is no essential difference between everyday discourse and literary discourse, and both of them are metaphorical or literary discourses; literariness is the commonality of all discourses. The purpose of Derrida's deconstruction is to equate philosophy, literature, and criticism from the perspective of holism.

Derrida also criticized Searle's “intentionality” theory of speech acts. Searle has introduced Edmund Husserl's concept of "intentionality" and independently advanced the theoretical research of "intentionality" from the perspective of speech acts, holding that there has been no connection whatever between the "intentionality" of speech acts and the "intentionality" in phenomenology. But in Derrida's view, Searle's intentionality still does not deviate from Husserl's framework. From a certain perspective, there are some similarities between Searle's intentionality theory and Husserl's intentionality theory, such as the directedness of intention, intentional structure, hierarchy, contents and so on. But, after all, the two people's positions, traditions and starting points are different, and international and domestic remarks also vary. In fact, the root of the disagreement on intentionality between Derrida and Searle lies in their views on iterability. For Searle, "meaning intentions" include both "representation intentions" and "communicative intentions"; meanings are derived from meaning intentions, while meaning intentions are the origin of meanings. That is to say, meaning intentions are the association of text proposition contents, words, etc., and the words are a form of intentional communication of meanings. Derrida criticized and deconstructed the communicative view that words are intentional meanings. He repeatedly clarified that he did not deny the existence of 
intentionality, but opposed the attitude that phenomenology and speech act theory would place intentionality and consciousness at the core. According to him, "intentionality" is a prior "différance" phenomenon; symbols and meaning intentions are all of différance. The "différance" of "intentionality" and meaning make the text form and the contents both iterate and change. The iterability divides the intentionality of the speaker or writer, and makes the intention not fully realized. Therefore, there will always be situations such as "words do not express the intention" or "words not fully express the intention", so that intentions and utterances do not fully correspond to each other. In general, Derrida's theory of speech interpretation intends to abandon the speaker's intention and intent, focusing on the differential movement of discourse itself.

\section{Reconstruction: Speech Acts as Social Systems}

From the perspective of a political and public activist, Jacques Derrida critically elucidated the thought of social conventions contained in the speech act theory. In fact, John Searle, just like Derrida, pays much attention to hot social and political issues and enjoys debating. He wrote a book The Campus War in 1971, and therefore, Searle can, to a great extent, refrain himself from being confined to the existing framework of analytic philosophy. It can be found that, Searle's speech acts theory contains both philosophical and linguistic significance as well as political and sociological significance that is above philosophy and linguistics. Although Searle considers the distinction between "everyday discourse" and "scientific discourse" and the treatment of literature as a parasitic discourse to be only a research strategy, which does not imply any moral judgment, he does not object to the application of speech act theory into social political researches, either. In Searle's view, Austin does not deny that literary discourses such as novels and dramas are part of everyday discourse; he only emphasizes that these words do not appear in everyday situations, but on the stage and in fictional texts. Searle put forward the concept of "social reality" and "institutional facts" early on, and later applied the speech act theory to sociological research and constructed social philosophy. As a social activist and public figure, Derrida also keenly discovered this, so he gave great enthusiasm and attention to the speech act theory. For him, literature, as a modern institution, is a non-religious, secularized system, i.e., a system that has got rid of theology and the church. "Literature as historical institution with its conventions, rules, etc., but also this institution of fiction which gives in principle the power to say everything, to break free of the rules, to displace them, and thereby to institute, to invent and even to suspect the traditional difference between nature and institution, nature and conventional law, nature and history." Therefore, another aspect of Derrida is that, from the sense of responsibility of a political and public activist, the theory of speech act has been elevated to a high political and social degree for review. His research of literature has blended thinking of literature as a system, i.e., "what is literature”, "where does literature come from”, and "how is literature treated”. "They do not only give them a theoretical, philosophical, or sociological form ... Their questioning is also linked to the act of a literary performativity and a critical performativity (or even a performativity in crisis)". His original intention of reflection on the binary opposition between literary discourse and everyday discourse was to critically deconstruct the "essential" ethical systems and norms, such as Western ethics, power and politics, and law, and to remove those governing and governed, and dominating and dominated acts from the perspective of thoughts and culture. In his view, it is necessary to create another ethical norm that is to dissolve this binary opposition. Derrida never doubted the moral and ethical implications of speech act theory. In his view, speech acts teach us to take our utterances seriously and be responsible for them. He paid much attention to issues such as how speech acts create the world and generate systems, history and reality, etc., for in his view, the speech act theory has considerable value for examining and solving problems such as political ethics, actions and responsibilities, law and power. It can be discovered that Derrida's deconstruction theory, especially his later deconstructive thoughts, embodies the dual concerns of language and reality, and contains an obvious view of "active engagement in the world", with strong political and realistic orientation. 


\section{References}

[1] Derrida, J. Limited Inc [M]. Evanston: Northwestern University Press, 1988: 33, 38.

[2] Derrida, J. Acts of Literature [M]. New York: Routledge, 1992, 42.

[3] Austin, J. L. How to Do Things with Words [M]. Oxford: Oxford University Press, 1962, 21-22.

[4] Culler, J. On Deconstruction [M]. New York: Cornell University Press, 2007, 113. 